\title{
Integrated protection system against progressive corn diseases
}

\author{
Anzor Shabatukov, and Liudmila Khromova \\ The branch of the RAS (Russian Academy of Sciences) Kabardino-Balkarian Research Center, Kirov \\ str., 224, 360004, Nalchik, Russia
}

\begin{abstract}
A biologized system of integrated protection against pathogens in corn crops is an important feature to reduce pesticide load. The use of new generation chemical fungicides with a low consumption rate and a wide spectrum of action against dominant infections, as well as their manufacturing application, will contribute to the improvement of corn agrocenosis. Due to the predicted, and subsequently planned yield, the phytosanitary situation will help in the development and implementation of effective protective measures to obtain biologically cleaner production of corn grain. Seed disinfection only solves the problem of seed infection. The appearance and harmfulness of boil smut also occurs during the growing season. Therefore, the transmission of primary infection occurs by plant residues and airborne droplets, which suggests the possibility of a systemic fungicide response to effectively contain not only the causative agent of boil smut, but also other types of infectious diseases on vegetative and reproductive bodies of corn. Investigations carried out in 2018-2020 to reduce the harmfulness of blister smut and fusarium head smut showed that seed infections are caused by a pronounced prevalence of diseases of roots, stalks and ears, such as fusarium, boil smut, alternaria, bacterial leaf burn, etc. The resistance degree of cross-breeds to dominant diseases depends on the infection terms, weather and climatic conditions and which corn body is more susceptible to these pathogens. Considering the possibility of infection penetration during the post-emergent period of corn development it is required to use system fungicides with a low consumption rate and prolonged action. In the Kabardino Balkarian Republic, the dominant corn disease is boil smut. It is known that the harmfulness of boil smut is higher with cob forms than with stem, leaf forms of infection, but in 2020 only the cob form of the disease was recorded, the dry and hot weather was the reason for this. In the steppe zone of the Kabardino Balkarian Republic, it is more expedient to use effective fungicides in the developed complex protection of corn crops against progressive harmful bodies.
\end{abstract}

\section{Introduction}

The use of increasing volumes of chemicals and plant protection products must be put on a strictly scientific basis. Therefore, the development and implementation of new features of the integrated protection system will become an urgent requirement to obtain more environmentally friendly corn grain products. The development of such a system of 
protective measures in the harmful pathocomplex response is an important area of research for corn production.

The object of research is a new cross-breed of Terek corn bred by ISKh KBNTs RAN.

The relevance of research involves monitoring of diseases as a system for monitoring the dynamics of the phytosanitary condition during the period of intensive growth and development of corn.

Ensuring plant protection in the period between the emergence of seedlings and their development will prevent or reduce the pathologies incidence, thereby increasing the yield of seed and industrial crops of corn.

The aim of the research is to develop an ecologically safer and more economically viable system for the integrated protection of corn against diseases in modern land husbandry.

The investigation objectives are as follows:

- to determine effective fungicides in the boil smut response and other dominant phytophages on experimental crops of corn;

- to reveal the influence of growth regulators and agrochemicals on the resistance of corn cross-breeds to unfavorable environmental factors and infectious diseases.

The scientific novelty of the research lies in the fact that for the first time in the arid steppe zone of the Kabardino-Balkarian Republic, a comparative effectiveness assessment of the chemical and biological fungicides used in the progressive pathogens response to corn diseases has been given.

One of the conditions for obtaining high yields of corn grain is the integrated protection of crops against pests, diseases and weeds using plant protection chemicals. It is known that bacterial preparations, along with the production of antibiotics are capable of triggering induced systemic resistance of plants, which can be successfully used in biological plant protection, which in some cases makes it possible to replace chemical agents. The problem of boil smut is completely solvable both by breeding for resistance and by reducing the sources of infection in the post-emergent period through the use of fungicides with a long period of protective action. Thus, the investigations carried out confirm the positive role of treating crops with Baileton fungicide, SP in protecting corn crops against diseases and increasing grain yield.

Agrotechnical measures associated with obtaining seeds that are practically clear of seed infections and suppress their activity during the growing season require constant investigation and improvement of plant protection methods.

\section{Materials and methods}

Field experiments were set up according to existing techniques [1,2]. Humus reserves in the $\mathrm{A}+\mathrm{B}$ horizon reach 256 tons/ha [3]. At the same time, the dependence of the appearance of progressive diseases on the main weather predictors and on the protective measures taken was revealed. At the same time, the biological effectiveness of the tested biofungicides against the indicated diseases was determined [4].

The use of plant protection products and their assessment were carried out in accordance with the "Methodological guidelines for state testing of fungicides, antibiotics and disinfectants of agricultural seeds" [5,6]. To clarify the hectare consumption rate of fungicides, microbiopreparations, agrochemicals, the corresponding catalogs were used [7, 8].

The following chemical fungicides were used as tested plant protection products: Baileton, SP (0.5 kg/ha), Abakus Ultra, SE (1.75 l/ha), Prozaro, KE (1 l/ha). The following biofungicides were tested: Orgamika S, Zh (1.4 1/ha); Pseudobacterin 3, Zh (0.7 1/ha); Fitolavin, VRK (21/ha); Rizoplan, Zh (1.0 1/ha); BisolbiSan, Zh (2.0 1/ha); Trichotsin, SP 
(0.04 kg/ha); Alirin B, TAB. (80 tab /ha); Gamair, TAB. (80 tab/ha). Chemical fungicides were used in a mixture with the Agromaster (18:18:18) agrochemical with a consumption rate of $2.5 \mathrm{~kg} / \mathrm{ha}$ and the Maxifol Dynamics growth regulator with a consumption rate of 1.0 1/ha [9]. Plants were treated with preparations using the Comfort - OE-12U shoulder sprayer. The total area of the plot was $56 \mathrm{~m}^{2}$ accounting plot area was $14 \mathrm{~m}^{2}$. During the growing season, observations and checks were carried out: the emergence of seedlings, flowering of panicle and corn cob, the total number of plants at the plot. In the phase of the grain full ripeness the percentage of attacked plants was calculated and the biological effectiveness of the preparations used against boil smut and other diseases was determined. The corn cobs were harvested manually in the full ripeness phase. The grain yield was taken into account by weighing, the data were processed by the method of variance analysis.

\section{Results and discussion}

One of the conditions for obtaining high yields of corn grain is the system of integrated protection of crops against pests, diseases and weeds using plant protection chemicals.

Experimental attempts laid down in the NPU No. 2 ISKh KBNTs RAN in 2018-2020 confirm the positive role of treatment with chemical fungicides: Baileton, SP; Abakus Ultra, SE and Prozaro, KE in the protection of corn against boil smut and other diseases and, as a result, an increase in grain yield. The agricultural technology of producing corn seeds clear of seed infections or suppressing their activity during the growing season requires constant investigation and improvement of the integrated protection system. High efficiency of fungicide Baileton, SP application against boil smut was revealed in the treatment of experimental plots in the phenophase of 7-8 corn leaves. As a result of calculating the weighted average percentage of attacked plants and determining the biological effectiveness, it was found that these values were $1.1 \%$ and $91.1 \%$, respectively.

In 2018-2020. on experimental crops of corn, boil smut was a progressive disease. The frequency of he bud form occurrence of boil smut was 2-3 times higher than the leaf and stem forms of this disease.

On the crops of the Terek corn cross-breed, 3 fungicides of chemical origin with different active ingredients were used: Baileton, SP; Abakus Ultra, SE and Prozaro, KE. The tests of fungicides in the boil smut response on the crops of the Terek corn cross-breed made it possible to give a comparative assessment of their biological and economic efficiency.

From the data in the table it can be seen that the option 2 shows the lowest percentage of the prevalence of boil smut $-1.1 \%$, which is $1.3 \%$ and $1.9 \%$ lower than in options 3 and 4 , respectively (Table 1).

Option 2 (Baileton, SP + Agromaster (18:18:18) + Maxifol Dynamics (st.)) shows the highest biological efficiency $(91.1 \%$ ), which is $10.6 \%$ and $15.5 \%$ higher than in options 3 and 4 . The yield was higher in option 2 and amounted to 4.1 ton/ha, which is 0.9 ton/ha more than the control and by 0.3 ton/ha and 0.6 ton/ha in options 3 and 4 .

Table 1. Comparative assessment of the biological and economic effectiveness of fungicides in the corn boil smut response (steppe zone, Terek cross-breed, 2018-2020)

\begin{tabular}{|l|l|l|l|l|l|l|}
\hline № & Fungicide names & $\begin{array}{l}\text { Application } \\
\text { rate } \\
\text { (l/ha, kg/ha) }\end{array}$ & $\begin{array}{l}\text { Average \% } \\
\text { of } \\
\text { prevalence }\end{array}$ & $\begin{array}{l}\text { Biological } \\
\text { efficiency,\% }\end{array}$ & $\begin{array}{l}\text { Crop } \\
\text { yield, } \\
\text { (ton/ha) }\end{array}$ & $\begin{array}{l}\text { Addition } \\
\text { yield, } \\
\text { ton/ha }\end{array}$ \\
\hline 1 & control & 12.3 & - & 3.2 & - \\
\hline
\end{tabular}




\begin{tabular}{|l|l|l|l|l|l|l|}
2 & $\begin{array}{l}\text { Baileton, SP } \\
+ \text { Agromaster } \\
(18: 18: 18)+ \\
\text { Maxifol } \\
\text { Dynamics (st.) }\end{array}$ & $0.5+2.5+1.0$ & 1.1 & 91.1 & 4.1 & 0.9 \\
\hline 3 & $\begin{array}{l}\text { Abakus Ultra, SE } \\
+ \text { Agromaster } \\
(18: 18: 18) \\
\text { Maxifol } \\
\text { Dynamics }\end{array}$ & $\begin{array}{c}1.75 \\
+2.5+1.0\end{array}$ & 2.4 & 80.5 & 3.8 & 0.6 \\
\hline 4 & $\begin{array}{l}\text { Prozaro, KE } \\
+ \text { Agromaster } \\
(18: 18: 18)+\end{array}$ & $\begin{array}{c}1.0+2.5 \\
\text { Maxifol } \\
\text { Dynamics }\end{array}$ & 3.0 & 75.6 & 3.5 & 0.3 \\
\hline$\cdot$ & \begin{tabular}{ll} 
HCP 05 \\
\hline
\end{tabular} & & & & & 0.1 \\
\hline
\end{tabular}

Based on the investigation results, it should be noted that all the studied tank mixtures of fungicides with agrochemicals (options 2, 3 and 4) on the crops of the Terek corn crossbreed showed a positive result in the boil smut response. Among them, the most effective in reducing harmfulness and increasing biological and economic efficiency was option 2, where a tank mixture of Baileton, Agromaster (18:18:18) and Maxifola Dynamics (st.) was used.

The obtained results of the effectiveness of plant protection products will be used in the development of an improved system, integrated protection of varieties and cross-breeds of field crops.

The experimental sowing of Terek $F_{1}$ corn was sprayed with biofungicides after the first irrigation, since a significant concentration of pathogens - polyphages - is concentrated in the upper soil layer. Plant diseases were recorded after 10, 20 and 30 days according to their symptoms, and then the causative agents of root and foot rot of different etiology were identified in laboratory conditions. At the same time, the dependence of the boil smut appearance, root and foot rot, mold fungi on weather predictors and ongoing agrotechnical measures was revealed. At the same time, the biological effectiveness of the tested biofungicides against the indicated diseases was determined .

As shown by the Table 2, all tested biofungicides in terms of biological effectiveness against root and foot rot of fungal and bacterial origin had low effectiveness. In the fusarium root rot response, variants 3 (Pseudobacterin 3, Zh), 4 (Fitolavin, VRK), 5 (Rizoplan, $\mathrm{Zh}$ ) distinguished, the values of which were above $50 \%$ and amounted to $41.3 \%$; $52.9 \% ; 47.8 \% ; 47.9 \% ; 41.7 \%$ respectively.

In the bacterial root and foot rot response, the efficiency was $50 \%$ higher in options 3 (Pseudobacterin 3, Zh), 4 (Fitolavin, VRK), 5 (Rizoplan, Zh), 6 (BisolbiSan, Zh) and amounted to $51.7 \% ; 78.4 \% ; 64.3 \% ; 69.5 \%$ respectively. In the causative agent response of Alternaria root rot, the following options have distinguished: 6 (BisolbiSan, $\mathrm{Zh}$ ), 7 (Trichocin, SP), 8 (Alirin B, tab.), where the biological effectiveness was important: $53.4 \%$; $51.5 \% ; 52.6 \%$ respectively. A representative of mold fungi - gray rot was comparatively controlled by only 2 preparations: Pseudobacterin-3, Zh - 50.3\% (option 3) and Alirin-B, tab. $-55.2 \%$ (option 8 ).

Biofungicides indicated in Table 2 had low biological effectiveness against the causative agent of boil smut and therefore the costs of purchasing preparations and spraying will not be justified.

According to the results of three years of investigations, it can be noted that, in the steppe arid zone, the species composition of pathogens was identified on corn crops, and the dominant phytopathogens were identified among them. The most progressive corn disease is boil smut as a result of poor resistance of sown corn cross-breeds. 
Table 2. Scheme for experiments set up on a biologized system of corn protection against diseases

(Terek $F_{1}$, steppe zone, KBR), 2018-2020

\begin{tabular}{|c|c|c|c|c|c|}
\hline \multirow{2}{*}{ No. } & \multirow{2}{*}{$\begin{array}{c}\text { Experimental } \\
\text { option }\end{array}$} & \multirow{2}{*}{$\begin{array}{l}\text { Consumption } \\
\text { rate (1/ha, kg/ha, } \\
\text { tab. /ha) }\end{array}$} & \multicolumn{3}{|c|}{ Biological efficiency, $\%$} \\
\hline & & & $\begin{array}{c}\text { Root and } \\
\text { foot rot }\end{array}$ & Cob mold & Boil smut \\
\hline 1 & $\begin{array}{l}\text { Control (out of } \\
\text { treatments) }\end{array}$ & - & - & - & - \\
\hline 2 & Orgamika S, Zh & 1,40 & 39,80 & 31,10 & 13,40 \\
\hline 3 & Pseudobacterin-3, Zh & 0,70 & 41,30 & 36,50 & 10,50 \\
\hline 4 & Fitolavin, VRK & 2,00 & 52,90 & 38,80 & 16,40 \\
\hline 5 & Rizoplan, Zh & 1,00 & 47,80 & 37,80 & 8,30 \\
\hline 6 & BisolbiSan, Zh & 2,00 & 47,90 & 42,20 & 9,70 \\
\hline 7 & Trikhotsin, SP & 0,04 & 33,60 & 34,00 & 14,80 \\
\hline 8 & Alirin B, Tab. & 80,00 & 41,70 & 36,40 & 10,40 \\
\hline 9 & Gamair, Tab. & 80,00 & 37,30 & 35,80 & 6,30 \\
\hline
\end{tabular}

Note: spraying was carried out the next day after the first watering in phenophase of 5-6 corn leaves

\section{Conclusion}

Based on the three year investigation results, the following conclusions can be drawn:

1. The use of a tank mixture of agrochemical fungicides and a growth regulator was effective, since the increase in grain yield according to the options was the following: from 0.3 ton/ha (Prozaro, KE) to 0.9 ton/ha (Baileton, SP).

2. On experimental crops of the Terek corn, the high biological effectiveness of the Baileton, SP fungicide in the boil smut response was determined, where the biological effectiveness was $91.1 \%$.

3. A comparative assessment of the biological effectiveness of 8 biofungicides showed that against the types of root and foot rot, fungal bacterial etiology, the following preparations were effective: Fitolavin, VRK; BisolbiSan, Zh and Rizoplan, Zh, where the efficiency was higher than others and met $52.9 \% ; 47.9 \% ; 47.8 \%$.

4. All studied microbiological preparations operated poorly against boil smut, since their effectiveness was lower than $16.4 \%$.

\section{References}

1. V .F. Peresypkin et al., Workshop on the methodology of experimental work in plant protectio (1989)

2. S. M. Pospelova, Workshop on plant protection (1988)

3. A. L. Ivanov, L. N. Molchanov, H. Sh.Tarchokov, M. M. Chochaev, Features of the adaptive-landscape farming system of the Kabardino-Balkarian Republic under total (2013)

4. A. I. Chumakov, T. I. Zakharova, Harmfulness of crop diseases (1990)

5. K. V. Novozhilov, Guidelines for state testing of fungicides, antibiotics and seed dressing agricultural crops (1985)

6. M. K. Khokhryakov, V. I. Potlaychuk et al., Identifier of crop diseases (1984)

7. AgroMaster Modern agrochemicals. Effective plant nutrition (2015) 
8. List of pesticides and agrochemicals permitted for use on the territory of the Russian Federation (2020)

9. A. Kh. Shabatukov, L. M. Khromova, Bulletin of the agro-industrial complex of Stavropol, 3, 78 (2019) 